\title{
Biochemical and Morphometric Analyses Show that Myelination in the Insulin-like Growth Factor 1 Null Brain Is Proportionate to Its Neuronal Composition
}

\author{
Clara M. Cheng, ${ }^{1}$ George Joncas, ${ }^{1}$ Rickey R. Reinhardt, ${ }^{1}$ Robert Farrer, ${ }^{2}$ Richard Quarles, ${ }^{2}$ Jeremy Janssen, ${ }^{1}$ \\ Michael P. McDonald, ${ }^{3}$ Jacqueline N. Crawley, ${ }^{3}$ Lynn Powell-Braxton, ${ }^{4}$ and Carolyn A. Bondy ${ }^{1}$ \\ ${ }^{1}$ Developmental Endocrinology Branch, National Institute of Child Health and Human Development, ${ }^{2}$ Myelin and Brain \\ Development Section, Laboratory of Molecular and Cellular Neurobiology, National Institute of Neurological Diseases and \\ Stroke, ${ }^{3}$ Section on Behavioral Neuropharmacology, National Institute of Mental Health, National Institutes of Health, \\ Bethesda, Maryland 20892, and ${ }^{4}$ Department of Cardiovascular Research, Genentech, San Francisco, California 94080
}

To elucidate the role of insulin-like growth factor 1 (IGF1) in the normal development of brain myelination, we used behavioral, biochemical, and histological analyses to compare the myelination of brains from $\operatorname{lgf1} 1^{-1-}$ and wild-type (WT) littermate mice. The studies were conducted at postnatal day 40 , at which time the $\operatorname{lgf1} 1^{-1-}$ mice weighed $\sim 66 \%$ less than wild-type mice. However, the $\operatorname{lgf1} 1^{-1-}$ brain weight was only reduced by $\sim 34 \%$. Formal neurological testing showed no sign of central or peripheral myelinopathy in $/ g f 1^{-1-}$ mice. Myelin composition was not significantly different, and myelin concentration, normalized to brain weight or protein, was equal in $\operatorname{lgf1}{ }^{-1-}$ and WT mice. Likewise, concentrations of myelin-specific proteins (MBP, myelin proteolipid protein, MAG, and 2',3'-cyclic nucleotide, $3^{\prime}$ phosphodiesterase) were not significantly different in $/ g f 1^{-/-}$ and WT mice. The myelin-associated lipids galactocerebroside and sulfatide were modestly reduced in $\operatorname{lgf1} 1^{-/-}$brains. Regional oligodendrocyte populations and myelin staining patterns were comparable in $I g f 1^{-/-}$and WT brains, with the notable exception of the olfactory system. The $\operatorname{lgf1^{-1-}}$ olfactory bulb was profoundly reduced in size and was depleted of mitral neurons and oligodendrocytes, and its efferent tracts were depleted of myelin.

In summary, this study shows that myelination of the $\operatorname{lgf1}{ }^{-1-}$ brain is proportionate to its neuronal composition. Where projection neurons are preserved despite the deletion of IGF1, as in the cerebellar system, oligodendrocytes and myelination are indistinguishable from wild type. Where projection neurons are depleted, as in the olfactory bulb, oligodendrocytes are also depleted, and myelination is reduced in proportion to the reduced projection neuron mass. These data make a strong case for the primacy of axonal factors, not including IGF1, in determining oligodendrocyte survival and myelination.

Key words: IGF1; oligodendrocyte; olfactory bulb; myelin basic protein (MBP); myelin proteolipid protein (PLP); 2',3'cyclic nucleotide, 3'-phosphodiesterase (CNPase); myelinassociated glycoprotein (MAG)
Insulin-like growth factor 1 (IGF1) and its cognate receptor are highly expressed in the developing brain. IGF1 is selectively expressed in maturing projection neurons of sensory and cerebellar relay systems during a relatively late phase of their development (Andersson et al., 1988; Ayer-Le Lievre et al., 1991; Bartlett et al., 1991; Bondy, 1991). IGF1 mRNA levels peak during the first few weeks of postnatal development and are profoundly reduced in most brain regions, with the exception of the olfactory bulb, after postnatal day 20 (P20) (Bondy, 1991). In response to injury, however, IGF1 gene expression is strongly induced in reactive astrocytes (Komoly et al., 1992; Lee et al., 1992). IGF1 receptor (IGFR) mRNA is most abundant in IGF1-expressing neurons (Bondy et al., 1992). IGF1 binding sites are coincident with IGFR mRNA in compact nuclear structures and are concentrated in synaptic zones adjacent to neurons expressing IGFR mRNA in laminar structures, suggesting that receptors are expressed predominantly on local neural processes (Bohannon et al., 1988, Lesniak et al., 1988). Little IGF binding or IGFR mRNA is detected in white matter (Bohannon et al., 1988; Les-

\footnotetext{
Received Feb. 27, 1998; revised April 24, 1998; accepted May 6, 1998.

Correspondence should be addressed to Dr. Clara Cheng, Building 10/10N262, 10 Center Drive, National Institutes of Health, Bethesda, MD 20892.

Copyright (C) 1998 Society for Neuroscience $0270-6474 / 98 / 185673-09 \$ 05.00 / 0$
}

niak et al., 1988; Marks et al., 1991; Bondy et al., 1992). Whereas neurons demonstrate constant or increasing levels of expression over the course of maturation, IGFR mRNA as a percent of total brain RNA decreases during postnatal development (Werner et al., 1989) because of increasing mRNA contribution from neuroglial cells, which express relatively little IGF1 receptor.

The normal developmental timing of IGF1 expression suggests that it is involved in nerve fiber growth, synaptogenesis, and/or myelination (Bondy, 1991). Recently, in vivo studies of transgenic mice ectopically overexpressing the IGF1 gene during later development under a metallothionein promoter revealed significant increases in brain size and myelin content (Carson et al., 1993; Ye et al., 1995). An earlier study on IGF1-targeted gene deletion $\left(I g f 1^{-1-}\right)$ brains reported hypomyelination based on a decrease in the size of anterior forebrain myelin tracts but did not investigate myelination in other brain regions or in the brain as a whole (Beck et al., 1995). To further examine the role of IGF1 in brain myelination, in the present study we have used biochemical, histological, and behavioral analyses to evaluate all aspects of myelination on a whole-brain and region-specific basis in the $I g f 1^{-/-}$ mouse brain using postnatal day 40 (P40) $I g f 1^{-/-}$and wild-type (WT) littermates. At this age, myelination of the mouse brain is essentially complete (Morell et al., 1972; Matthieu et al., 1973). 


\section{MATERIALS AND METHODS}

Animal tissue. The $\operatorname{Igf1^{-/-}}$ mouse line used in this study, which had been bred into a CD1 inbred line for more than six generations, was approved by the National Institute of Child Health and Human Development Animal Use and Care Committee and was generated at Genentech, Inc. (San Francisco, CA) (Powell-Braxton et al., 1993). Igf1 ${ }^{-1-}$ and WT littermate mice were genotyped as described previously (Powell-Braxton et al., 1993) and killed by decapitation at P40 for experimental comparison. For biochemical analysis and frozen section preparation, brains were removed, snap frozen, and stored at $-70^{\circ} \mathrm{C}$ until used. Sections $10 \mu \mathrm{m}$ thick were cut sagittally at $-20^{\circ} \mathrm{C}$, thaw-mounted onto poly-Llysine-coated slides, and stored at $-70^{\circ} \mathrm{C}$.

Myelin isolation. Brain myelin was isolated by sucrose density gradient centrifugation as described by Quarles et al. (1985). Briefly, brains were homogenized in $0.32 \mathrm{M}$ sucrose $(1 \mathrm{gm} / 20 \mathrm{ml})$ and layered over an equal volume of $0.85 \mathrm{M}$ sucrose. After centrifuging at 75,000 $\times \mathrm{g}$ for $30 \mathrm{~min}$, myelin was collected from the interface and osmotically shocked with water on ice for $30 \mathrm{~min}$. The large myelin fragments were sedimented at $12,000 \times g$ for $20 \mathrm{~min}$, resuspended in a buffer containing $10 \mathrm{~mm}$ Tris-HCl, pH 8.0, and $1 \mathrm{~mm}$ EDTA for protein concentration determination by the method of Bradford (1976).

Immunoblotting. Protein (25 mg) from total brain homogenate or myelin fractions was loaded on precast 4-20\% SDS-polyacrylamide gels (Novex, San Diego, CA) and transferred to nitrocellulose membranes using an electrophoretic transfer cell (Bio-Rad, Hercules, CA). The primary antibodies used for immunoblotting were obtained from the following sources: anti-2', $3^{\prime}$-cyclic nucleotide, $3^{\prime}$-phosphodiesterase (CNPase) (1:400) and anti-myelin proteolipid protein (PLP) (1:250) from Chemicon (Temecula, CA); anti-myelin basic protein (MBP) (1:1000) from Sternberger Monoclonals (Baltimore, MD); and B11F7 anti-myelin-associated glycoprotein (MAG) monoclonal antibody as previously described (Doberson et al., 1985). After incubation with horseradish peroxidase-linked secondary antibodies, protein bands were visualized on Kodak (Rochester, NY) XAR film by ECL detection reagents (Amersham, Cleveland, OH). A digital image of the immunoblots was made, and the relative amounts of myelin-specific proteins in WT and Igf1 ${ }^{-1-}$ samples were compared using the NIH Image 1.57 program.

Immunohistochemistry. Immunohistochemistry was performed by the avidin-biotin-immunoperoxidase method. Briefly, frozen brain sections were fixed in $4 \%$ formaldehyde for $10 \mathrm{~min}$, quenched in $3 \% \mathrm{H}_{2} \mathrm{O}_{2}$ for 10 min, and then blocked in $10 \%$ normal serum for $30 \mathrm{~min}$, followed by incubation overnight at $4^{\circ} \mathrm{C}$ with primary antibodies. The anti-MAG antibody was as described above, and the anti-PLP was purchased from Biogenesis (Sandown, NH). These antibodies were used at dilutions of 1:100 and 1:50, respectively. Sections were incubated with biotinylated secondary antibodies (1:400) for $30 \mathrm{~min}$. The signal was detected and amplified using the ABC peroxidase method (Vector Laboratories, Burlingame, CA), and visualized with 3,3'-diaminobenzidine. Sections were counterstained with methyl green.

Lipid analysis. Total brain homogenates prepared as described for myelin isolation were centrifuged at $100,000 \times g$ for $1 \mathrm{hr}$. Pellets were resuspended in water and centrifuged again at $100,000 \times g$ for another hour. Resulting pellets, considered as total membrane fraction, were suspended in water, and lipids were extracted with chloroform/methanol (C/M; $1: 1, \mathrm{v} / \mathrm{v})$ so that the final ratio of chloroform/methanol/water was 5:5:1. Neutral glycosphingolipids and sulfatide were separated from gangliosides by a modification of the phase partitioning method originally

Table 1. Comparison of brain weight, protein, and myelin content in $\operatorname{Ig} \mathrm{fl}^{-1-}$ mice and wild-type littermates

\begin{tabular}{lrrrr} 
& \multicolumn{4}{c}{$\begin{array}{l}\% \\
\text { change }\end{array}$} \\
\hline Brain weight $(\mathrm{mg})$ & $489.06 \pm 4.76$ & $324.70 \pm 6.57$ & $34 \Downarrow$ & $<0.0001$ \\
Protein $(\mathrm{mg})$ & $48.16 \pm 0.61$ & $33.14 \pm 0.85$ & $31 \Downarrow$ & $<0.0001$ \\
Myelin $(\mathrm{mg})$ & $2.84 \pm 0.16$ & $1.78 \pm 0.07$ & $37 \Downarrow$ & 0.012 \\
Myelin $(\mu \mathrm{g}) /$ brain $(\mathrm{mg})$ & $5.77 \pm 0.56$ & $5.52 \pm 0.50 \Leftrightarrow$ & 0.75 \\
Myelin $(\mu \mathrm{g}) /$ protein $(\mathrm{mg})$ & $59.78 \pm 7.84$ & $55.23 \pm 6.32 \Leftrightarrow$ & 0.66 \\
\hline
\end{tabular}

Brain myelin fractions were prepared and assayed as described in Materials and Methods. Values are mean \pm SEM of $n=6$ for both groups. The data for $I g f 1^{-/}$ and wild-type mice were compared using ANOVA followed by Scheffe $t$ test. The $\Downarrow$ symbol indicates a decrease. The $\Leftrightarrow$ symbol indicates no change. described by Folch et al. (1957). The C/M extract was adjusted to a ratio of $2: 1(\mathrm{C} / \mathrm{M}, \mathrm{v} / \mathrm{v})$ with the addition of chloroform, and aqueous and organic phases were generated by adding $0.74 \% \mathrm{KCl}$. The lower organic phase was subjected to mild alkaline methanolysis to destroy alkali-labile glycerophospholipids. The lower phase glycosphingolipid fractions representing equal amounts of protein were chromatographed on $10 \mathrm{~cm}$ silica gel 60 high performance thin layer chromatography (HPTLC) plates (Merck, Darmstadt, Germany) in chloroform/methanol/water (65: 25:4). Glycolipids were detected with Orcinol reagent, and galactocerebroside and sulfatide were identified by their comigration with standards. A digital image of the orcinol-stained HPTLC plate was made, and the relative amounts of galactocerebroside and sulfatide in WT and IGF1 null samples were compared using the NIH Image program.

Luxol fast blue-periodic acid Schiff-hematoxylin stain. For histological staining of myelin sheaths, frozen brain sections were fixed in $4 \%$ formaldehyde, stained in $0.1 \%$ Luxol blue at $60^{\circ} \mathrm{C}$ overnight, and differentiated in $0.05 \%$ lithium carbonate for $30 \mathrm{sec}$, followed by $70 \%$ ethanol for $10 \mathrm{sec}$ (Margolis and Pickett, 1956). After rinsing in distilled water, sections were oxidized in $0.5 \%$ periodic acid and then stained in $0.5 \%$ Schiff's solution for $15 \mathrm{~min}$. Sections were finally counterstained with hematoxylin.

In situ hybridization. In situ hybridization was performed as described previously (Bondy and Lightman, 1989), and oligomer sequences of PLP and MBP used for probe synthesis were as described by Komoly et al. (1992).

Morphometry. The area of whole-brain sections and structures, includ-

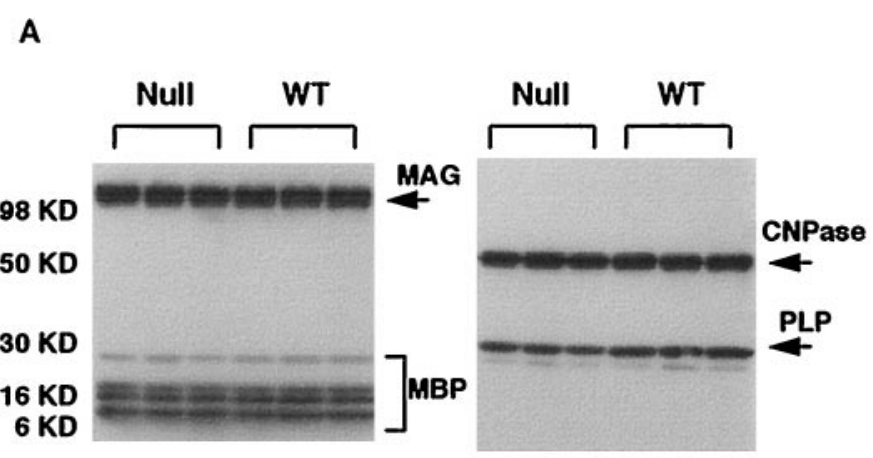

B

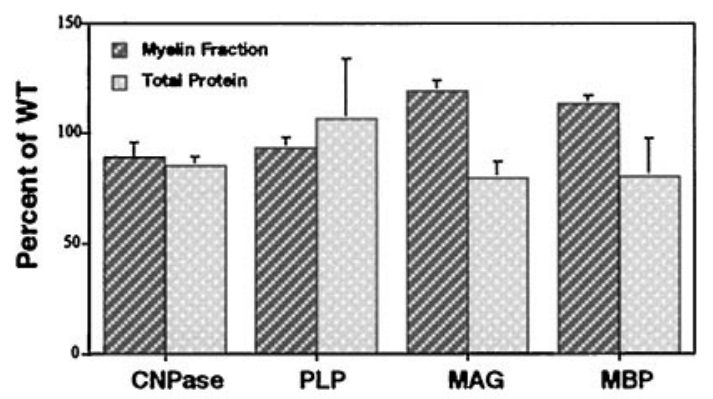

Figure 1. Immunoblot analysis of myelin-specific proteins in $\operatorname{Igf1^{-1-}}$ (Null) and wild-type (WT) brains. A, Representative immunoblots of myelin fraction proteins isolated by sucrose density gradient centrifugation and separated on $4-20 \%$ polyacrylamide gels. The proteins were blotted onto nitrocellulose membranes and probed with antibodies against MAG, MBP (left), CNPase, and PLP (right). The bands representing these proteins are marked by arrows and appear at the positions of expected molecular weight: MAG, $100 \mathrm{kDa}$; MBP, 14, 17, 18, and 21.5 $\mathrm{kDa}$; CNPase, $48 \mathrm{kDa}$; PLP, $25 \mathrm{kDa}$. These blots show data from three $\mathrm{WT}$ and three $\operatorname{Igf1^{-1-}}$ mice; similar results were obtained with additional groups. $B$, Quantitation of CNPase, PLP, MAG, and MBP levels determined by immunoblotting of total brain protein and brain myelin fractions. Protein bands from the blots shown in $A$ and blots from other independent trials were quantified using computer-assisted image analysis. Data are expressed as mean \pm SEM of percentage of WT values $(n=$ 6 for both WT and $I g f 1^{-1-}$ groups). None of the values represents a significant difference between $\operatorname{Ig} f 1^{-1-}$ and wild type. 

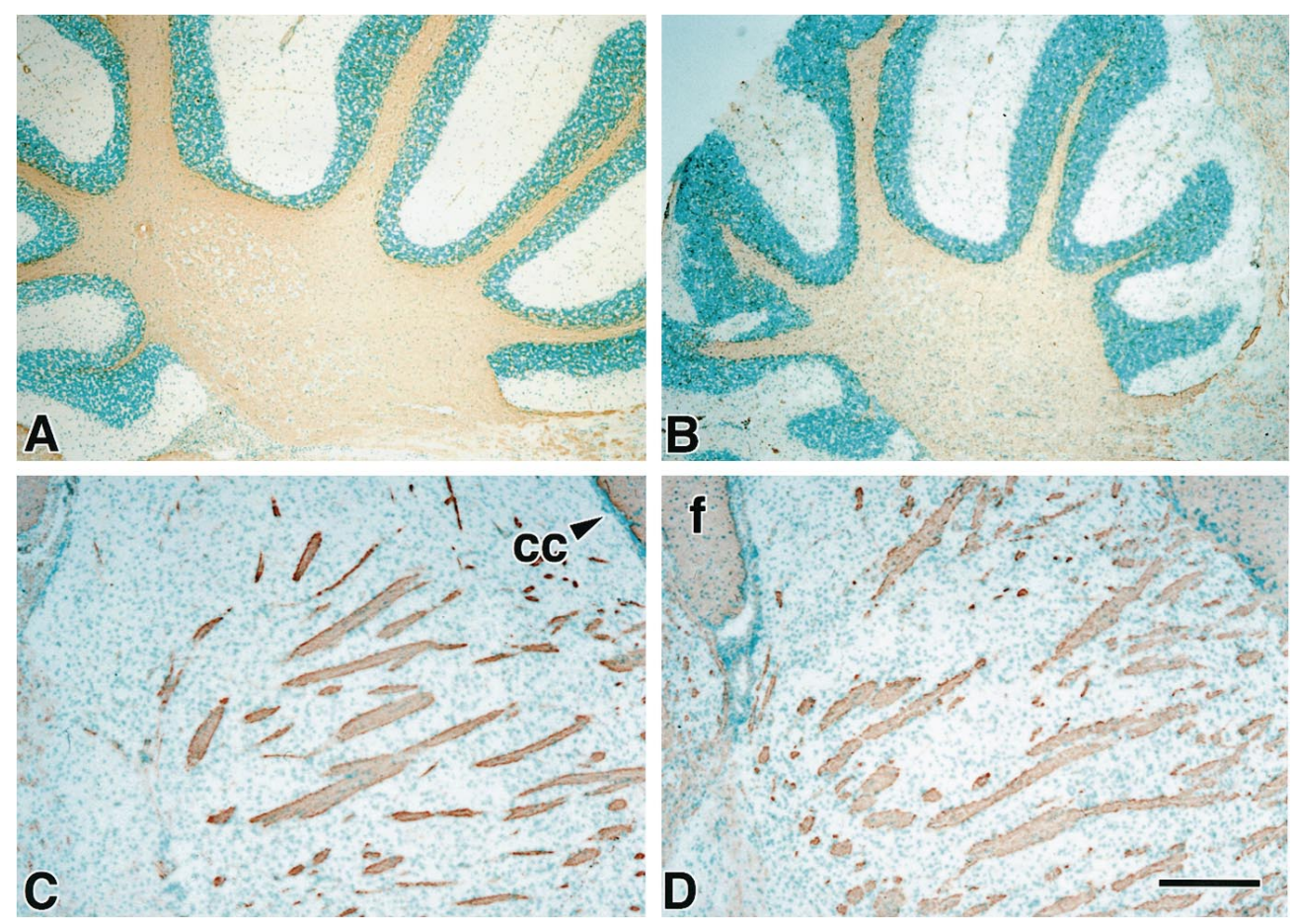

Figure 2. Immunohistochemical comparison of the regional expression of PLP in WT $(A, C)$ and $\operatorname{Igf1^{-1-}}$ brains $(B, D)$. Anatomically matched sagittal P40 brain sections were probed by antiPLP antibodies visualized with 3,3'diaminobenzidine (brown) and counterstained with methyl green. Micrographs show the homogeneous distribution of PLP in myelinated tracts of the cerebellum $(A, B)$ and striatum $(C, D) . c c$, Corpus callosum; $f$, fimbria. Scale bar, $200 \mu \mathrm{m}$.

ing the olfactory bulb, anterior commissure (AC), and cerebellum, was measured using computerized image analysis. Anatomically matched sagittal sections were digitized using a solid-state video camera. The structures were outlined by cursor control, and the areas were obtained in pixels using the NIH Image program (see above). The width of cerebellar medullary ray forming the stalk of the four and five lobules at the level of the origin of the preculminate and primary fissures was measured on micrographs taken at $200 \times$. Two to four independent measurements per animal were obtained for each structure. The evaluation of cell density and PLP mRNA-positive cell density was done manually with a microscope at $200-400 \times$ and on micrographs taken at the same magnifications. PLP mRNA-positive cells were defined as having at least five exposed silver grains.

Neurological testing. Thirty mice (14 WT and $16 \operatorname{Igf1^{-/-}}$ ) were used for behavioral testing. Mice were 35-45 d old at the start of testing. Weights were recorded at the time of testing to facilitate analysis of data by size as well as genotype differences. For general neurological function, a battery of tests was performed as described previously (Irwin, 1968; Crawley and Paylor, 1997), including righting, air-righting, whiskerorienting, eye blink, pinna twitch, and Preyer auditory reflexes, as well as reaching response and response to an approaching object. Rotorod performance was tested as described by Liu et al. (1997), and wire-hang latency was measured according to the method of Sango et al. (1996).

\section{RESULTS}

\section{Myelin content}

At P40, Igf1 ${ }^{-/-}$mice weigh $\sim 66 \%$ less than WT littermates $\left(8.92 \pm 1.27\right.$ vs $25.98 \pm 1.79 \mathrm{gm} ; n=6$ for each group). Igf1 ${ }^{-/-}$ brain weight, however, is only reduced by approximately onethird (Table 1). Myelin is decreased by $37 \%$ in the $\operatorname{Igf1^{-/-}}$ brain compared with the WT, in parallel with the reduction in brain size (Table 1). When myelin is normalized to brain weight, there is no significant difference between $\operatorname{Igf1} 1^{-1-}(5.52 \pm 0.50 \mu \mathrm{g}$ myelin $/ \mathrm{mg}$ brain) and wild type $(5.77 \pm 0.56 \mu \mathrm{g}$ myelin $/ \mathrm{mg}$ brain). Similar results were obtained when the data were expressed as micrograms of myelin per milligrams of total brain protein (Table 1). Thus, total myelin content in the $I g f 1^{-/-}$brain is reduced in proportion to brain size, and myelin concentration is equivalent in $I g f 1^{-/-}$and WT brains.

\section{Myelin proteins}

The expression of the major myelin proteins was compared in both total protein preparations and purified myelin fractions (Fig. 1). MAG, MBP, PLP, and CNPase levels were equal in myelin fractions from $I g f 1^{-1-}$ and WT brains (Fig. $1 B$ ). In total protein blots, MAG and MBP were reduced by $\sim 15 \%$ in $\mathrm{Igf1}^{-/-}$brains, but this difference was not statistically significant (Fig. 1B).

Cellular patterns of PLP and MAG protein localization were evaluated by immunohistochemistry. Figure 2 shows very similar intensity and distribution of PLP immunoreactivity in white matter tracts of WT and $I g f 1^{-/-}$mice. Parallel sections probed with anti-MAG antibody also revealed no evidence of a decrease in MAG intensity or altered distribution in $I g f 1^{-/-}$brains (data not shown). In situ hybridization histochemistry comparing regional PLP and MBP gene expression in WT and $I g f 1^{-/-}$brains reveals virtually identical neuroanatomical patterns of expression (Fig. 3), except for a substantial reduction in both transcripts in the $I g f 1^{-/-}$olfactory bulb (see below).

\section{Myelin lipids}

Characteristic lipid components of myelin were compared by thin-layer chromatography (Fig. 4). Galactocerebroside and sulfatide levels per milligram of total protein were reduced by $\sim 25 \%$ in the $I g f 1^{-/-}$brains. Luxol blue histochemical staining was used to assess myelin concentration in specific brain regions (Fig. 5). The anterior limb of the anterior commissure (al/AC) and the olfactory tract demonstrated a profound reduction in Luxol staining in $\operatorname{Ig} f 1^{-1-}$ brains compared with wild type (Fig. $5 A-D$ ), in contrast to the essentially normal pattern of staining obtained in other brain structures, e.g., the cerebellum (Fig. 5E,F). The anterior limb consists of axons originating from the olfactory bulb, which is unique among brain structures in demonstrating continued high levels of IGF1 expression during adulthood (Bondy, 1991). 

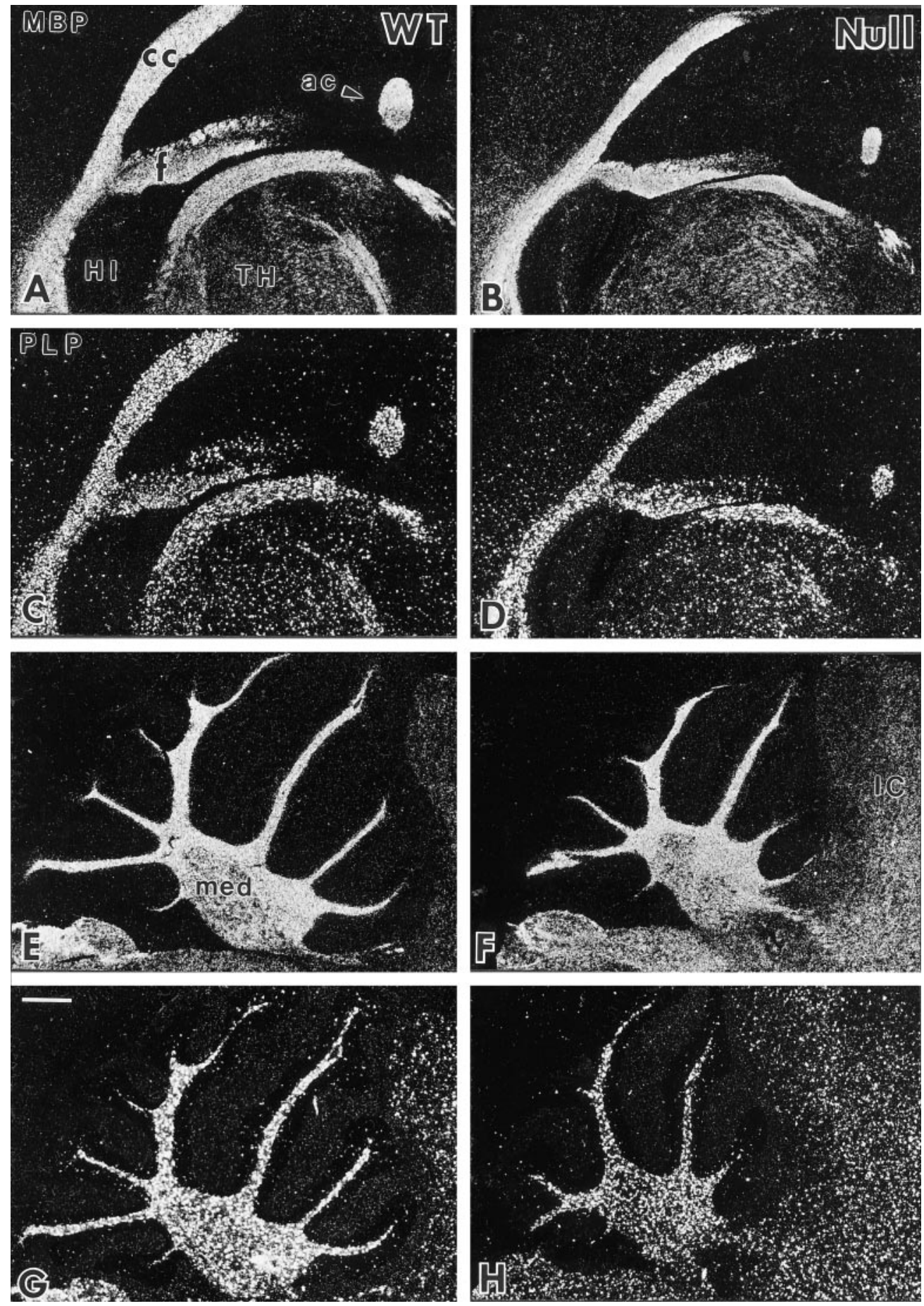

Figure 3. Comparison of PLP and MBP gene expression in the anterior forebrain and cerebellum of wild-type (WT, left panels) and Igf1 ${ }^{-/-}$mice (Null, right panels) by in situ hybridization. Serial sagittal brain sections of WT and $I g f 1^{-1-}$ brains were hybridized to ${ }^{35} \mathrm{~S}$-labeled oligomer probes for MBP $(A, B, E, F)$ and PLP $(C, D, G, H)$. Dark-field micrographs show the hybridization signal as white grains. $a c$, Anterior commissure; $c c$, corpus callosum; $f$, fimbria; HI, hippocampal formation; $I C$, inferior colliculus; med, cerebellar medulla; $T H$, thalamus. Scale bar, $400 \mu \mathrm{m}$.

\section{Regional morphometry and oligodendrocyte distribution}

Given the marked reduction in size and myelin staining of the al/AC, we compared the size of the olfactory bulb and other brain structures, such as the cerebellum, where myelination appears normal. The olfactory bulb was reduced in area by $60 \%$, whereas the whole-brain section and cerebellar areas were reduced by only $25-30 \%$ in $I g f 1^{-1-}$ compared with WT brains (Table 2). The projection neurons of the Igf1 ${ }^{-/-}$cerebellar cortex were significantly increased in density such that their total number is probably equal in WT and $I g f 1^{-/-}$brains, whereas mitral neuron density was not increased in the $I g f 1^{-/-}$olfactory bulb (Table 2), suggesting at least a $60 \%$ reduction in the number of olfactory projection neurons, given the $60 \%$ decrease in olfactory size.

Oligodendrocyte populations were evaluated by counting PLP mRNA-positive (PLP+) cells in terms of number per area and as 
A

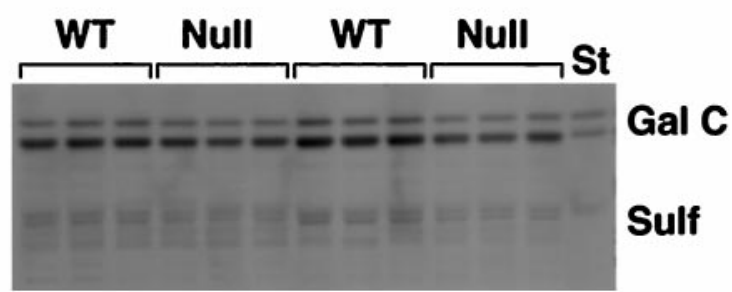

B

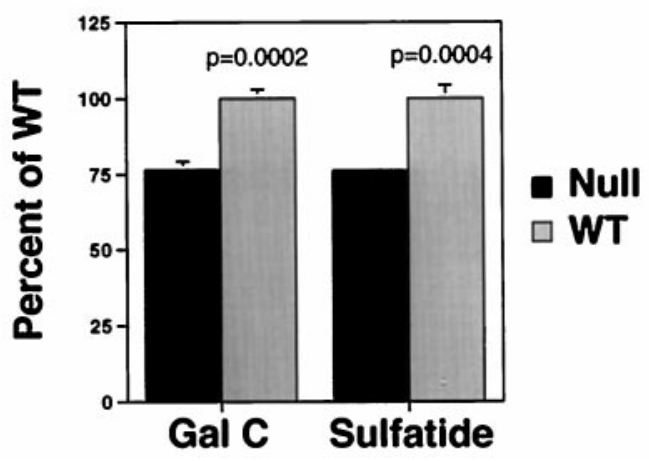

Figure 4. Myelin lipids in WT and $I g f 1^{-/-}$brains extracted from equal amounts of total protein demonstrated by thin layer chromatography. Orcinol-stained bands are identified as galactocerebroside $(\mathrm{Gal} \mathrm{C})$ or sulfatide (Sulf) by comparison of the comigrating standards (St) in $A$. The bands were quantified by the NIH Image analysis program, and the results are expressed as mean \pm SEM of percentage of wild type $(B)$. a percentage of all cells in a given area. PLP + cells were increased in density in the Igf1 ${ }^{-/-}$cerebellum and posterior limb of the $\mathrm{AC}$, but their numbers were equal or reduced in the anterior limb of the AC and olfactory bulb (Fig. 6, Table 2). The reduction was most pronounced in the external plexiform layer but was also significant in the mitral cell layer (Fig. 6A-D, Table 2).

\section{Neurological function}

All reflexes and measures of gross sensory function were normal in $\operatorname{Igf1} 1^{-/-}$mice. $I g f 1^{-/-}$mice performed better than wild types on the wire-hanging latency test, which measures neuromuscular function and grip strength (this may be partially explained by their lesser weight, because smaller mice tend to perform better on this test), whereas there was an $\sim 30 \%$ decrease in rotorod performance for the $I g f 1^{-/-}$mice (Table 3 ). Evaluation of gait by comparing paw print tracings showed no abnormality in the $I g f 1^{-/-}$mice, with shorter distances between steps proportionate to their reduced size (data not shown).

\section{DISCUSSION}

This study shows that brain myelin is proportionate to brain mass in $\operatorname{Ig} f 1^{-/-}$mice and that these mice show no overt behavioral signs of dysmyelination, suggesting that myelination is not significantly impaired despite IGF1 deletion. The proportionate reduction in myelin content, demonstrated by equivalent whole-brain myelin concentrations, is likely explained by the reduced dimensions of neuronal processes in these dwarf mice, and in some cases, e.g., the olfactory bulb, by the depletion of neurons. In brain structures in which the projection neurons are preserved, oligodendrocyte numbers and myelination are preserved in WT
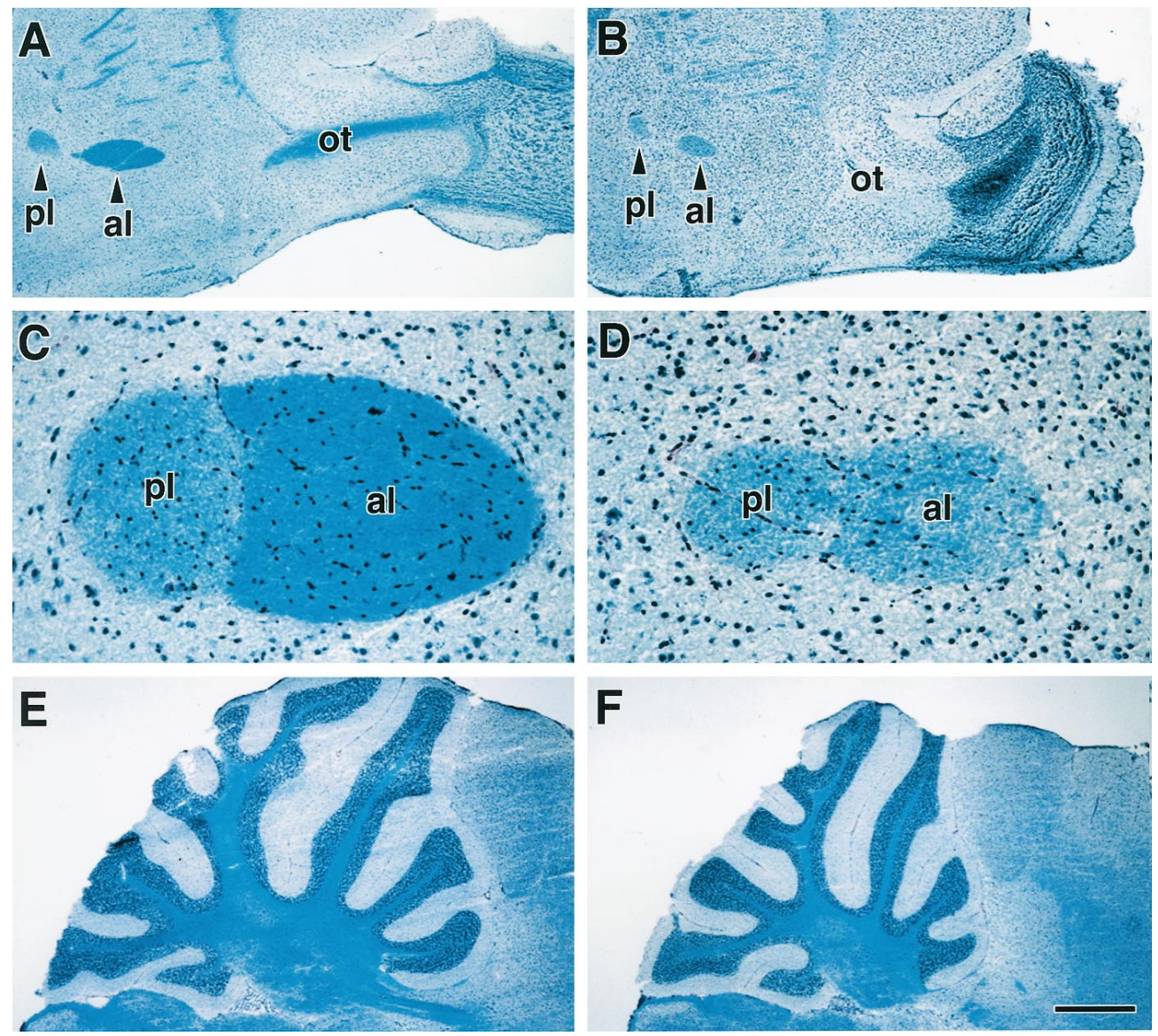

Figure 5. Luxol blue myelin staining in WT $(A, C, E)$ and $I g f 1^{-1-}(B, D, F)$ brains. $A$ and $B$ show the olfactory tract (ot) leading into the olfactory bulb at low magnification. The anterior and posterior limbs ( $a l$ and $p l$, respectively) of the AC are seen on the left side of $A$ and $B . C$ and $D$ show ACs at higher magnification at a medial level in which two limbs have joined, showing that the anterior limb is deeply stained in the wild type but very faintly stained in the Igf1 ${ }^{-I-}$. $E$ and $F$ compare Luxol staining in the cerebellum. The lipophilic Luxol stain is marine blue, and hematoxylin-stained nuclei are navy blue. Scale bar: $A, B, E, F, 400 \mu \mathrm{m} ; C, D$, $50 \mu \mathrm{m} ; E, F, 200 \mu \mathrm{m}$. 
Table 2. Regional morphometric analyses

\begin{tabular}{|c|c|c|c|c|}
\hline & Wild-type & $\operatorname{Ig} f 1^{-1-}$ & $\begin{array}{l}\% \\
\text { change }\end{array}$ & $p$ \\
\hline \multicolumn{5}{|l|}{ Whole brain } \\
\hline Area $\left(\times 10^{4}\right)$ & $3.46 \pm 0.10$ & $2.62 \pm 0.05$ & $24 \Downarrow$ & $<0.00$ \\
\hline \multicolumn{5}{|l|}{ Cerebellum } \\
\hline Area $\left(\times 10^{3}\right)$ & $3.84 \pm 0.38$ & $2.71 \pm 0.15$ & $30 \Downarrow$ & 0.03 \\
\hline plp cell $\left(/ 200 \mu \mathrm{m}^{2}\right)$ & $25.50 \pm 1.54$ & $30.30 \pm 1.07$ & $19 \Uparrow$ & 0.03 \\
\hline wm diam $(\mu \mathrm{m})$ & $108 \pm 11$ & $88 \pm 12$ & $19 \Downarrow$ & 0.02 \\
\hline Purkinje cells $/ 250 \mu \mathrm{m}$ & $12.6 \pm 0.70$ & $17.3 \pm 0.6$ & $37 \Uparrow$ & 0.000 \\
\hline \multicolumn{5}{|l|}{ Olfactory bulb } \\
\hline $\begin{array}{l}\text { Area }\left(\times 10^{3}\right) \\
\text { plp cells }\end{array}$ & $3.18 \pm 0.16$ & $1.25 \pm 0.23$ & $60 \Downarrow$ & $<0.000$ \\
\hline epl $(\%)$ & $3.84 \pm 0.36$ & $1.48 \pm 0.30$ & $62 \Downarrow$ & 0.002 \\
\hline $\mathrm{ml}(\%)$ & $3.18 \pm 0.91$ & $0.91 \pm 0.20$ & $71 \Downarrow$ & 0.005 \\
\hline mitral cells $/ 250 \mu \mathrm{m}$ & $6.08 \pm 0.78$ & $6.15 \pm 0.52$ & $\Leftrightarrow$ & 0.964 \\
\hline \multicolumn{5}{|c|}{ Anterior commissure } \\
\hline $\begin{array}{l}\text { Area }\left(\times 10^{3}\right) \\
\text { plp cell }(/ 200 \mu \mathrm{m})\end{array}$ & $0.074 \pm 0.015$ & $0.037 \pm 0.015$ & $51 \Downarrow$ & 0.003 \\
\hline al & $58.00 \pm 4.60$ & $59.20 \pm 4.41$ & $\Leftrightarrow$ & 0.855 \\
\hline $\mathrm{pl}$ & $40.80 \pm 5.85$ & $54.50 \pm 4.99$ & $34 \Uparrow$ & 0.129 \\
\hline
\end{tabular}

$\overline{\text { All morphometric analyses were done on anatomically matched parasagittal sec- }}$ tions. Data are expressed as mean \pm SEM with $n=4-6$ for each observation. plp cells, PLP mRNA-positive cells, presumed to be oligodendrocytes. These cells were scored as a percentage of all cells in the indicated zones in each section. Counting them on an area basis was thought to be less accurate because the cell density of these regions is so low. However, their number was also significantly diminished when counted per $500 \mu \mathrm{m}^{2}$ (data not shown). Whole-brain, cerebellum, anterior commissure, and olfactory bulb areas were obtained using image analysis as explained in Materials and Methods and are given in pixels. The number of mitral and Purkinje cells were counted microscopically using an eyepiece reticule at $200 \times$. epl, External plexiform layer; ml, mitral cell layer; wm, cerebellar white matter. The $\Downarrow$ symbol indicates a decrease. The $\uparrow$ symbol indicates an increase. The $\Leftrightarrow$ symbol indicates no change.

and $I g f 1^{-/-}$mice, despite the loss of IGF1, but in structures where the projection neurons are depleted, oligodendrocyte numbers and myelin staining are selectively diminished, suggesting a primary role for neural factors other than IGF1 in oligodendrocyte survival and myelination. The present findings are consistent with the neurological phenotype of an $\operatorname{Ig} f 1^{-1-}$ man who is severely mentally retarded but who shows no evidence of dysmyelination (Woods et al., 1996). Furthermore, these data suggesting a primary neuronal function for IGF1 in brain development agree with the primarily neuronal patterns of IGF1 and IGFR expression during brain development (Bondy and Lee, 1993).

Beck et al. (1995), in a previous study of the $\operatorname{Ig} f 1^{-/-}$brain, reported that IGF1 gene disruption resulted in brain hypomyelination. This conclusion was based primarily on the observation of an apparently disproportionate reduction in size of white matter tracts in the anterior forebrain. Using anterior coronal sections to evaluate myelination, they found an $\sim 70 \%$ reduction in AC area and medial corpus callosum thickness. Given that whole-brain size was reduced by only one-third, it was concluded that there was a selective reduction in myelination affecting the $\operatorname{Ig} f 1^{-/-}$ brain. However, that study did not assess myelination in other brain areas or the brain as a whole and did not investigate the neural structures giving rise to the affected forebrain myelin tracts. In contrast, the present study used an integrated wholebrain approach to the evaluation of myelination in the $I g f 1^{-/-}$ brain. We examined neuroanatomical patterns of myelination in the $I g f 1^{-1-}$ mouse from brainstem to olfactory bulb and found that white matter structures were proportionate in size to relevant neuronal structures. The brain as a whole and most component structures were reduced in size by approximately one-third compared with wild type, and myelination was reduced in a parallel manner.

Throughout most of the $\operatorname{Ig} f 1^{-/-}$brain, cell density is increased (Beck et al., 1995; present study), suggesting that much of the decrease in brain size is attributable to decreased neuropil. For example, the cerebellum is reduced in area by $30 \%$, but Purkinje cells and oligodendrocytes are increased in density, such that their total numbers may be very similar in WT and $I g f 1^{-/-}$ cerebella. Myelination, in terms of the size of cerebellar white matter tracts and intensity of staining for myelin and myelinspecific proteins, appears quite normal throughout the $\operatorname{Ig} f 1^{-/-}$ cerebellum, despite the fact that IGF1 is normally highly expressed by inferior olivary, Purkinje, and deep cerebellar projection neurons during development (Bondy, 1991). This observation suggests that if the system projection neurons survive despite the lack of IGF1, oligodendrocytes survive and appropriate myelination occurs. The $\operatorname{Ig} f 1^{-/-}$olfactory bulb, in contrast to the cerebellum, was reduced in size by $60 \%$ and had a reduced number of projection neurons and oligodendrocytes. Central olfactory white matter tracts were correspondingly reduced in size by $60 \%$. Our study thus confirms the marked reduction in the size and myelin staining of the anterior limb of the AC as noted by Beck et al. (1995), but shows that this defect relates to olfactory neural hypoplasia, rather than being emblematic of a generalized defect in myelination. Together, the observations in cerebellum and olfactory bulb suggest that oligodendrocyte survival and myelination are determined by neural factors other than IGF1.

The anterior limb of the AC consists of olfactory axons crossing to the contralateral olfactory cortex, whereas the posterior limb comprises decussating temporal lobe axons. The present study shows markedly reduced myelin staining in the anterior but not posterior limb of the $I g f 1^{-1-}$ AC, indicative of a selective impairment of the olfactory component. As a possible explanation for this marked defect in the $I g f 1^{-/-}$olfactory system, we note that mitral neurons normally express IGF1 throughout life, suggesting a sustained and apparently critical dependency on this anabolic peptide, in contrast to other systems in which projection neurons demonstrate transient IGF1 expression during development (Bondy, 1991). The reduced axon number in the AC (Beck et al., 1995) stems from the reduced number of mitral cells in the hypoplastic $I g f 1^{-/-}$olfactory bulb, and the reduced myelination of remaining axons probably reflects an attenuation in size or electrical activity of axons arising from IGF1-deficient olfactory projection neurons. Substantial evidence indicates that oligoden-

Figure 6. Oligodendrocyte concentration in olfactory bulb $(A-D)$ and cerebellar medulla $(E-H)$. PLP mRNA-positive cells are taken to be oligodendrocytes. In this figure, each bright-field micrograph is paired with a matching dark-field illumination showing the PLP mRNA-positive cells. The wild-type $(W T)$ olfactory bulb $(A, B)$ is much larger than that of the $\operatorname{Ig} f 1^{-1-}$ (Null) $(C, D)$. The number of mitral neurons and PLP mRNA-positive cells are both reduced in the Igf1 ${ }^{-1-}$. ep, External plexiform layer; $i g$, internal granular layer; ip, internal plexiform layer; $m$, mitral cell layer; $o t$, olfactory tract. PLP mRNA-positive cells are shown at higher magnification on the cerebellar medulla of WT $(E, F)$ and $\operatorname{Ig} f 1^{-1-}(G, H)$ brain sections. Scale bar: $A-D, 200 \mu \mathrm{m} ; E-H, 50 \mu \mathrm{m}$. 


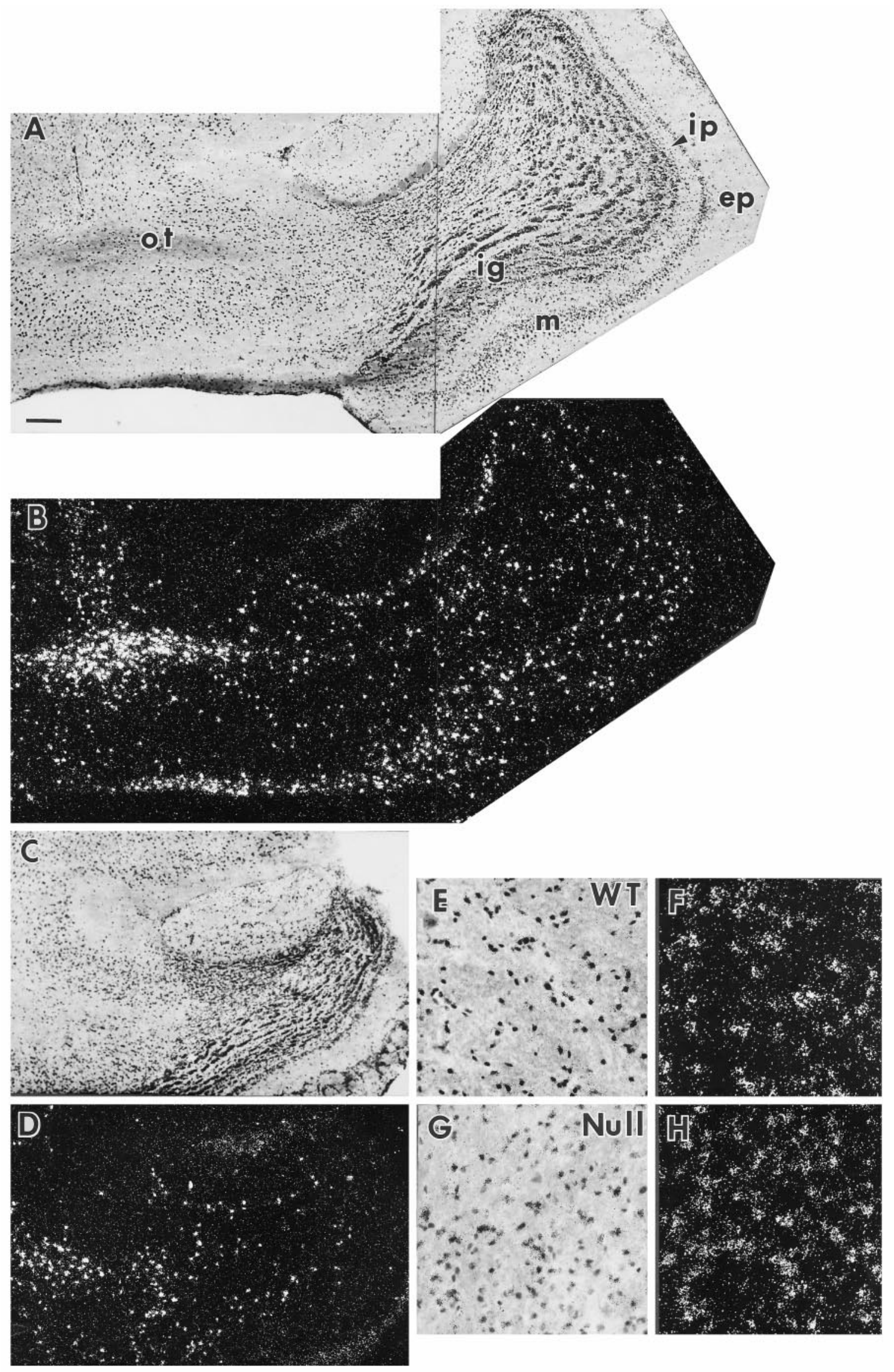




\begin{tabular}{llll}
\hline \multicolumn{4}{l}{ Table 3. Neurological testing of $\boldsymbol{I g f ^ { - / - }}$ mice and wild-type littermates } \\
& Wild-type & $I g f^{-/-}$ & $p$ \\
\hline Rotorod performance & $\begin{array}{l}227.7 \pm 24.1 \\
(n=14)\end{array}$ & $\begin{array}{l}156.6 \pm 19.0 \\
(n=16)\end{array}$ & $<0.05$ \\
Wire-hang latencies & $\begin{array}{l}136.4 \pm 44.0 \\
(n=9)\end{array}$ & $\begin{array}{l}229.5 \pm 31.2 \\
(n=11)\end{array}$ & NS \\
& $(n=9)$
\end{tabular}

Values are mean \pm SEM of number of animals indicated for each group. The rotorod performance tests the ability of mice to maintain balance on a rotating cylinder. Mice that did not fall or cling during the $300 \mathrm{sec}$ trial period were given a score of 300 . Wire-hang latency measures the ability of mice to hang upside down from a wire screen. Mice that did not fall during the $300 \mathrm{sec}$ trial period were given a score of 300. The data were compared using ANOVA followed by Bonferronicorrected $t$ tests. NS, Not significant.

drocyte survival and myelin sheath formation are linked to axonal contact, with larger or more active axons stimulating more oligodendrocytes to survive and produce more extensive myelination (Barres et al., 1992, 1993; Barres and Raff, 1993). By analogy with the winnowing of peripheral nerves to match the size of target zones, the axon appears to be the target zone of oligodendrocytes, whose number is thus appropriately matched to specific axonal myelin needs.

Beck et al. (1995) also noted a reduction in vertical diameter, or thickness of the medial limb of the corpus callosum. The corpus callosum is more heterogeneous than the AC, consisting of populations of crossing cortical axons, which vary at each rostrocaudal and mediolateral plane, making it difficult to know to which specific neuronal subpopulation its size should be compared at any given level. It is possible that their measurements included the hippocampal commissure underlying the corpus callosum. This structure, containing crossing dentate gyrus axons, should reflect the disproportionate reduction in size of the dentate gyrus, noted by the same authors (Beck et al., 1995). The fact that on a whole-brain basis myelin and myelin-specific protein concentrations are equal in $\mathrm{WT}$ and $I g f 1^{-1-}$ brains suggests that the attenuation of the corpus callosum is proportional to a corresponding diminution in neural mass. Supporting this view, a recent analysis of the peripheral nervous system in $\mathrm{Ig} f 1^{-1-}$ mice showed reduced axonal diameter with myelination proportionate to axon size and no evidence of peripheral myelinopathy (Gao et al., 1997).

The view that myelination in $I g f 1^{-1-}$ mice is essentially matched to neural mass and presumably needs is supported by functional data. Primary myelin deficiencies are associated with neurological consequences, including tremor and impaired motor skills and coordination, whereas $I g f 1^{-1-}$ mice demonstrate normal or modestly impaired neuromuscular functions. Further support for the view that IGF1 is not primarily involved in myelination is provided by the finding that a young man nullizygous for IgfI is mentally retarded but does not have any signs of dysmyelination on clinical examination or brain imaging (Woods et al., 1996).

The idea that IGF1 had a role in brain myelination began with in vitro studies showing that IGF1 promotes oligodendrocyte proliferation, survival, and differentiation (for review, see McMorris and McKinnon, 1996). However, the present study shows that, with the exception of the olfactory bulb (in which projection neurons are also depleted), oligodendrocyte numbers and differentiation are not deficient in the $I g f 1^{-/-}$brain, demonstrating that IGF1 does not have an essential or generalized role in oligodendrocyte development in vivo. It could be argued that the role of IGF1 is taken over by IGF2 in the $I g f 1^{-/-}$brain, because
IGF1 and IGF2 both activate the IGF1 receptor and IGF2 is expressed in brain. However, the entirely different developmental regulation and spatiotemporal patterns of expression of these two peptides (Bondy et al., 1992) make it difficult to imagine interchangeable actions in brain development. The "redundancy" rationalization is particularly unconvincing, because the $I g f 1^{-/-}$ brain has multiple defects that are clearly not compensated by IGF2, including the olfactory bulb hypoplasia noted in the present study, as well as selective deficits in dentate gyrus granule cells and in a subpopulation of striatal neurons, as demonstrated by Beck et al. (1995).

The fact that IGF1 does not seem to have a major role in developmental myelination does not mean that it is not important in repair processes called into play after nervous system injury. IGF1 expression is induced in reactive astrocytes responding to ischemia (Lee et al., 1992) and demyelinating insults (Komoly et al., 1992), and IGFR expression is enhanced in injured oligodendrocytes (Komoly et al., 1992), and administration of exogenous IGF1 improves remyelination after injury (Yao et al., 1995). The prominent effects of IGF1 on oligodendrocytes in vitro may actually be explained by the fact that culture is essentially an injury model system, with the cells struggling to survive and function after trauma in adverse conditions, deprived of their normal nurturing environment.

Observations in transgenic mice overexpressing IGF1 under the control of a metallothionein promoter have been invoked to support a primary role for IGF1 in myelination (Carson et al., 1993). This model involves the ectopic expression of IGF1 from unidentified brain cells during a relatively late phase of development after normal endogenous IGF1 expression has subsided (except for the olfactory bulb). Both brain size and myelin content are increased in the transgenic, but DNA content and oligodendrocyte numbers are not, so it appears that the increased brain mass is attributable primarily to increased cell size and/or process growth. A recent investigation of this transgenic model (Ye et al., 1995) showed that axonal diameter is significantly increased in IGF1-overexpressing brains and that myelin sheath thickness correlates positively with axonal diameter. If, as discussed above, myelination is induced by neuronal fiber growth and/or activity, then a straightforward explanation for the findings in the transgenic model is that IGF1 overexpression late in development stimulates excessive growth in size and/or activity of axons (and possibly dendrites), which, in turn, stimulates additional oligodendrocyte biosynthetic activity and myelination.

The view that the primary effects of IGF1 are on neurons reflects the normal in vivo patterns of IGF1 and IGFR expression, which are primarily neuronal. For example, in the olfactory bulb, IGF1 is expressed by mitral and tufted neurons (Bondy, 1991), and the IGFR is concentrated in the glomerular, plexiform, and mitral layers but not in the olfactory nerve or tract (Werther et al., 1989; Marks et al., 1991). The most likely scenario is that IGF1, released locally from olfactory projection neuron soma and dendrites, acts in an autocrine or paracrine manner on the projection neurons, enhancing their survival, growth, and activity. In the absence of IGF1, fewer projection neurons survive, and those that do are asthenic. As a secondary result of this neuraxonal deficiency, oligodendrocytes are reduced in number and make less myelin, perhaps attributable to loss of axonal factors that normally stimulate oligodendrocytes. This is not likely to include IGF1, because IGFR expression is not normally detected in these neuroglial cells in vivo and because there seems to be no problem with oligodendrocyte survival or myelination in other brain struc- 
tures, such as the cerebellum, in which the projection neurons survive despite the lack of IGF1. Thus, the data from studies in the $I g f 1^{-/-}$brain and the IGF1 overexpression brain are best explained by the simple hypothesis that IGF1 stimulates neuronal process growth, which in turn stimulates myelin formation.

In summary, in this study we show that myelination of the $I g f 1^{-1-}$ brain is proportionate to its neuronal composition whether analyzed on a region-by-region or whole-brain basis. We show that where projection neurons are preserved, as in the cerebellar system, oligodendrocytes and myelination are robust and indistinguishable from wild type. Where projection neurons are depleted, as in the olfactory bulb, oligodendrocytes are also depleted, and myelination is reduced in proportion to the reduced mitral mass. These data make a strong case for the primacy of axonal factors other than IGF1 in determining oligodendrocyte survival and myelination.

\section{REFERENCES}

Andersson IK, Edwall D, Norstedt G, Rozell B, Skottner A, Hansson H-A (1988) Differing expression of insulin-like growth factor I in the developing rat cerebellum. Acta Physiol Scand 132:167-173.

Ayer-Le Lievre C, Stahlbom PA, Sara VR (1991) Expression of IGF-I and -II mRNA in the brain and craniofacial region of the rat fetus. Development 111:105-115.

Barres BA, Hart IK, Coles HSR, Burne JF, Voyvodic JT, Richardson WD, Raff MC (1992) Cell death and control of cell survival in the oligodendrocyte lineage. Cell 70:31-46.

Barres BA, Jacobson MD, Schmid R, Sendtner M, Raff MC (1993) Does oligodendrocyte survival depend on axons? Curr Biol 3:489-497.

Barres BA, Raff MC (1993) Proliferation of oligodendrocyte precursor cells depends on electrical activity in axons. Nature 361:258-260.

Bartlett WP, Li XS, Williams M, Benkovic S (1991) Localization of insulin-like growth factor-I mRNA in murine central nervous system during postnatal development. Dev Biol 147:239-250.

Beck KD, Powell-Braxton L, Widmer H-R, Valverde J, Hefti F (1995) Igf1 gene disruption results in reduced brain size, CNS hypomyelination, and loss of hippocampal granule and striatal parvalbumincontaining neurons. Neuron 14:717-730.

Bohannon NJ, Corp ES, Wilcox BJ, Figlewicz DP, Dorsa DM, Baskin DG (1988) Localization of binding sites for IGF-I in the rat brain by quantitative autoradiography. Brain Res 444:205-213.

Bondy CA (1991) Transient IGF-I gene expression during the maturation of functionally related central projection neurons. J Neurosci 11:3442-3455.

Bondy CA, Lee WH (1993) Patterns of insulin-like growth factor and IGF receptor gene expression in the brain: functional implications. Ann NY Acad Sci 692:33-43.

Bondy CA, Lightman SL (1989) Developmental and physiologic regulation of aldose reductase mRNA expression in renal medulla. Mol Endocrinol 3:1409-1416.

Bondy CA, Werner H, Roberts CT, LeRoith D (1992) Cellular pattern of type I insulin-like growth factor receptor gene expression during maturation of the rat brain: comparison with insulin-like growth factors I and II. Neuroscience 46:909-923.

Bradford MM (1976) A rapid and sensitive method for the quantitation of microgram quantities of protein utilizing the principle of protein-dye binding. Anal Biochem 72:248-254.

Carson M, Behringer R, Brinster R, McMorris FA (1993) Insulin-like growth factor I increases brain growth and central nervous system myelination in transgenic mice. Neuron 10:729-740.

Crawley JN, Paylor R (1997) A proposed test battery and constellations of specific behavioral paradigms to investigate the behavioral phenotypes of transgenic and knockout mice. Horm Behav 31:197-211.

Dobersen MJ, Hammer JA, Noronha AB, Maclntosh TD, Trapp BD, Brady RO, Quarles RH (1985) Generation and characterization of monoclonal antibodies to the myelin-associated glycoprotein. Neurochem Res 10:423-437.

Folch J, Lees M, Sloane-Stanley GH (1957) A simple method for the isolation and purification of total lipids from animal tissues. J Biol Chem 226:497-509.

Gao W-Q, Shinsky N, Ingle G, Beck K, Elias KA, Powell-Braxton L (1997) IGF-I deficient mice show reduced peripheral nerve conduction velocities, decreased fiber size and respond to exogenous IGF-I treatment. Mol Cell Neurosci, in press.

Irwin S (1968) Comprehensive observational assessment. I. A systematic, quantitative procedure for assessing the behavioral and physiologic state of the mouse. Psychopharmacologia 13:222-257.

Komoly S, Hudson LD, Webster HD, Bondy CA (1992) Insulin-like growth factor I gene expression is induced in astrocytes during experimental demyelination. Proc Natl Acad Sci USA 89:1894-1898.

Lee WH, Clemens JA, Bondy CA (1992) insulin-like growth factors in the response to cerebral ischemia. Mol Cell Neurosci 3:36-43.

Lesniak MA, Hill JA, Kiess W, Rojeski M, Pert CB, Roth J (1988) Receptors for IGF-I and -II: autoradiographic localization in rat brain and comparison to receptors for insulin. Endocrinology 123:2089-2099.

Liu Y, Hoffmann A, Grinberg A, Westphal H, McDonald MP, Miller KM, Crawley JN, Sandhoff K, Suzuki K, Proia RL (1997) Mouse model for GM2 activator deficiency, the AB variant of GM2 gangliosidosis. Proc Natl Acad Sci USA 94:8138-8143.

Margolis G, Pickett J (1956) New applications of the Luxol fast blue myelin stain. Lab Invest 5:459-474.

Marks JL, Porte D, Baskin DG (1991) Localization of type I IGF receptor mRNA in the adult rat brain by in situ hybridization. Mol Endocrinol 5:1158-1168.

Matthieu JM, Widmer S, Herschkowitz N (1973) Biochemical changes in mouse brain composition during myelination. Brain Res 55:391-402.

McMorris FA, McKinnon RD (1996) Regulation of oligodendrocyte development and CNS myelination by growth factors: prospects for therapy of demyelinating disease. Brain Pathol 6:313-329.

Morell P, Greenfield S, Constantino-Ceccarini E, Wisniewski H (1972) Changes in the protein composition of mouse brain myelin during development. J Neurochem 19:2545-2554.

Powell-Braxton L, Hollingshead P, Warburton C, Dowd M, Pitts-Meek S, Dalton D, Gillett N, Steward TA (1993) IGF-I is required for normal embryonic growth in mice. Genes Dev 7:2609-2617.

Quarles RH, Barbarash GR, MacIntosh TD (1985) Methods for the identification and characterization of glycoproteins in central and peripheral myelin. In: Research methods in neurochemistry, Vol 6 (Marks N, ed), pp 303-357. New York: Plenum.

Sango K, MaDonald MP, Crawley JN, Mack ML, Tifft CJ, Skop E, Starr CM, Hoffmann A, Sandhoff K, Suzuki K, Proia RL (1996) Mice lacking both subunits of lysosomal-hexosaminidase display gangliosidosis and mucopolysaccharidosis. Nat Genet 13:348-352.

Werner H, Woloschak M, Adamo M, Shen-Orr Z, Roberts CT, LeRoith D (1989) Developmental regulation of the rat insulin-like growth factor I receptor gene. Proc Natl Acad Sci USA 86:7451-7455.

Werther GA, Hogg A, Oldfield BJ, McKinley MJ, Figdor R, Mendelsohn F (1989) Localization and characterization of IGF-I receptors in rat brain and pituitary gland using in vitro autoradiography and computerized densitometry: distinct distribution from insulin receptors. J Endocrinol 1:369-377.

Woods KA, Camacho-Hubner C, Savage MO, Clark AJL (1996) Intrauterine growth retardation and postnatal growth failure associated with deletion of the insulin-like growth factor I gene. N Engl J Med 335:1363-1367.

Yao DL, Liu X, Hudson LD, Webster HD (1995) Insulin-like growth factor I treatment reduces demyelination and up-regulates gene expression of myelin-related proteins in experimental autoimmune encephalomyelitis. Proc Natl Acad Sci USA 92:6190-6194.

Ye P, Carson J, D'Ercole AJ (1995) In vivo actions of insulin-like growth factor-I (IGF-I) on brain myelination: studies of IGF-I and IGF binding protein-1 (IGFBP-I) transgenic mice. J Neurosci 15:7344-7356. 